\title{
South China Sea: Perspectives, Challenges and India's Options
}

\author{
Commodore SL Deshmukh, NM (Retd)*
}

\begin{abstract}
"Siddhirbhavati Karmaja" (Sasnkrit Quote) the Sanskrit quote meaning "Success is born of action" reflects well on trade prowess of a nation. An undisputable importance of the Seas would be seen from the fact that $90 \%$ of the world trade transits through the Sea lanes of communications (SLOCs). As sea trade has indelible impact on national economies, a global race to claim and control various parts of oceans/seas has become fiercer over the years. Further, in view of the current geo-political scenario, requirement for adherence to the existing international laws- related to seas, economic zones, Sea Lanes of Communication has assumed greater importance. .
\end{abstract}

Accordingly, the South China Sea would always remain India's business, in view of its national security and economic well-being. It is important to note that the South China Sea is not China's sea, but a global common. It has been an important sea-lane of communication since the very beginning, and passage has been unimpeded over the centuries, Indian Traders have sailed these waters for well over 1,500 years - there is ample historical and archaeological evidence of a continuous Indian trading presence. Thus the linkage to ancient Indian Trade Routes, and the historical rights for Free Passage. This sea would also remain strategically important for India, as nearly \$200 billion of Indian trade passes through the South China Sea and because of its socio- economic linkages with ASEAN, China, Japan and the Republic of Korea.

Keeping in mind the strategic implications, this article attempts to analyse issues revolving around South China Sea situation as relevant to India and explore options best for India's strategic interests.

Keywords: Sea Trade, Ancient Trade Routes, India, South China Sea, SLOC, Maritime Power, strategic interests, China, global common, ASEAN

*Commodore SL Deshmukh, NM (Retd) served the Indian Navy for over three decades as a specialist in maintenance of fighter aircraft and ASW helicopters. He is currently the Senior Vice President of Sun Group's Aerospace \& Defence vertical. 


\section{South China Sea: Perspectives, Challenges and India's Options}

\section{Introduction}

"Siddhirbhavati Karmaja" (Sanskrit Quote) the Sanskrit quote meaning "Success is born of action" reflects well on trade prowess of a nation. From time immemorial, India has been a maritime nation. Historical evidence is available that Maritime Trade existed thousands of years ago between India and other parts of the world:-

a) India: Dr Avantika Lal (Lal, 2015) stated that “ The navy (321 BCE - 297 BCE) in ancient India carried out three roles: it was used to transport troops to distant battlefields, participate in actual warfare, and was primarily meant for protecting the kingdom's trade on sea and navigable rivers and the maritime trade routes. The lucrative and highly developed trade with Egypt, West Asia, Greece, and Rome led to the growth of navies along India's west coast facing the Arabian Sea, and many dynasties ruling in various parts of India also maintained navies to protect the trade being conducted through huge rivers such as the Ganga. On the east coast facing the Bay of Bengal maritime activities led to colonizing expeditions to Southeast Asia. The Indian maritime tradition has carried on since then...."

b) Egypt: Gregory P Gilbert (Gilbert, 2007) observes that "That maritime history of Egypt dates back to the Early Dynastic period (c. 3050-2686 BCE). If the evidence for boats in Egyptian prehistory is considered, instances where sea power has influenced the rise in social complexity within Egyptian culture start to emerge. It is possible to see that Egyptian civilisation is not only predicated on the existence of the Nile but also on the development of a maritime Egypt and the utilisation of an early form of sea power. Ideas were communicated, objects were traded and wars were fought; with sea power as a facilitator."

c) Iran: Britannica Encyclopaedia (2020) has recorded, "Probably the greatest of the Achaemenian rulers was Cyrus II (reigned 559-c. 529 BCE), who actually established the empire and from whose reign it is dated; Darius I (522-486), who excelled as an administrator and secured the borders from external threats; and Xerxes I (486-465), who completed many of the projects begun by Darius. During the time of Darius I and 
Xerxes I, the empire and its economic power extended as far west as Macedonia and Libya and as far East as the Hyphasis (Beās) River; it stretched to the Caucasus Mountains and the Aral Sea in the north and to the Persian Gulf and the Arabian Desert in the south".

Thus it is evident that understanding about Maritime Trade and need for Freedom of Navigation dates back to thousands of years. Coming to the modern era, with global trade having emerged as the backbone of national economies, indisputable importance of the Seas would be discernible through the data from UNCTAD, as given in the the table (Table 1) below:

Table 1: Development of goods loaded worldwide by type of cargo_(Millions of tons)

\begin{tabular}{|l|l|l|l|l|} 
Year & Total goods & Crude oil & Other tanker trade & Dry cargo \\
\hline 1973 & 3274 & 1514 & 353 & 1407 \\
1978 & 3550 & 1604 & 296 & 1650 \\
1983 & 3231 & 1069 & 392 & 1770 \\
1988 & 3735 & 1160 & 456 & 2119 \\
1993 & 4330 & 1443 & 502 & 2385 \\
1998 & 5631 & 1548 & 534 & 3549 \\
2003 & 6480 & 1690 & 533 & 4257 \\
2008 & 8231 & 1785 & 957 & 5489 \\
2013 & 9513 & 1738 & 1091 & 6685 \\
2018 & 11005 & 1886 & 1308 & 7811
\end{tabular}

Data courtesy: UNCTAD (2019c). Review of Maritime Transport 2019. United Nations publication. Sales no. E.19.II.D.20.

As sea trade has an indelible impact on national economies, a global race to claim and control various parts of oceans/seas has become fiercer over the years. Importantly, China's assertive behaviour in South China Sea (SCS) has presented evident challenge to freedom of navigation to SCS littoral countries and by implication to global maritime trade. "Its defiance of the award 
of International Tribunal at The Hague in 2016" (Phillips, T., Holmes, O., \& Bowcott, O., 2016, July 12) amply demonstrated its intention to uphold its own interests over international law. Recent developments in SCS, including aggressive military posturing against Japan, US and unprovoked ingressions in eastern Ladakh against India point to the delicate geopolitical situation that is emerging. Seen from the context of China's huge investments in developing CPEC in conjunction with Pakistan, the seemingly bilateral dispute between India and Pakistan over Sir Creek appears to fit into larger Chinese interests in Indo-Pacific. In view of the current geo-political situation, this paper attempts to study the broad outline of Maritime Trade and analyse issues concerning South China Sea and India's strategic imperatives at a broader level with a view to evolve possible solutions.

Keeping in view the objective of this paper, it is divided into three Parts, viz., Ancient Maritime Trade and its linkages to modern era, South China Sea Dispute seen from the global perspective and its implications for India. In the end we attempt to draw some conclusion and recommendations.

\section{Part 1: Ancient Maritime Trade and Linkages to Modern Era}

\section{Old Trade Routes and their significance}

Maritime Silk routes, as depicted in the map (Fig 1) below, assumed importance during the $15^{\text {th }}$ to $19^{\text {th }}$ century, as seen in Marine Insight Report ( MI, N, N, 2018) that states :

As marine trade picked up and east began connecting with west, maritime trade routes began flourishing like never before. Silk trade was one of the trades that benefitted the most from it. Considering the demand for commodities as luxurious as silk, several silk routes came into existence as more and more traders from west travelled to east in search of better options. 


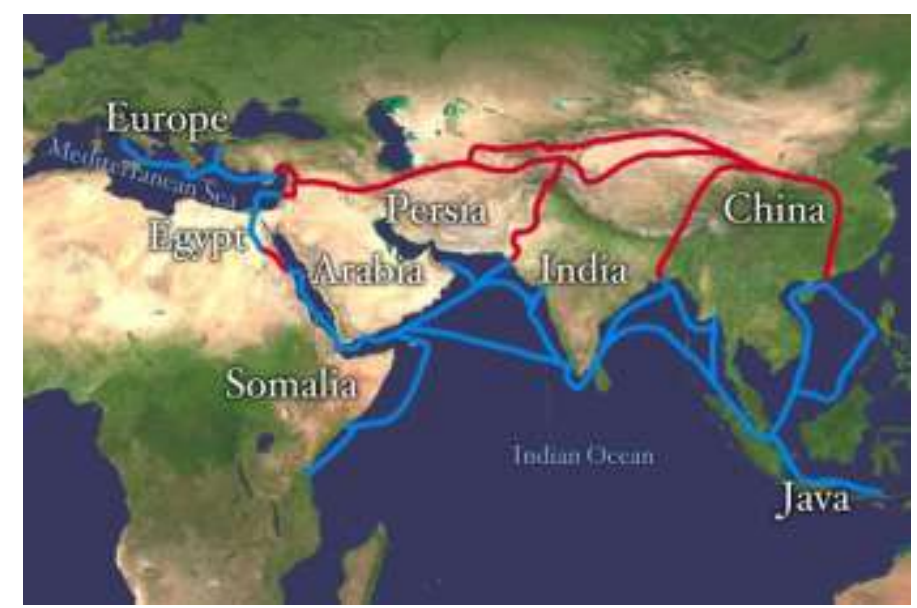

Source: Wikimedia.org

The $15^{\text {th }}$ century, 6400 mile long Silk Road ran from china to Europe via India and West Asia. Caravans of silk and other trading goods often travelled through this silk route. The "Great Wall of China" and many other fortifications were built to protect the trade from en-route attacks.

\section{Maritime Trade Routes}

Maritime Silk Routes on the other hand stretching from Naka to Alexandria and further to Venice, connecting South East Asia; India, Arabian Peninsula and Africa, perhaps originated even before the land based Silk Route. Historical evidences discussed above give ample proof that a maritime silk route and silk and spice trade over this route are the oldest trading operations recorded in the history.

Southern China's Xuwen port was probably the first port of marine Silk Road, because of its closeness to sea and easy access. Due to then technology limitations for ships construction for long passages ports like Xuwen became most important spots for hottest silk trade routes. This point would highlight importance of Sea Trade, Marine Boundaries and that of the South China Sea, in current day environment.

\section{Ancient Indian Maritime Trade Routes}

Fig 2: Ancient Indian Maritime Trade Routes 


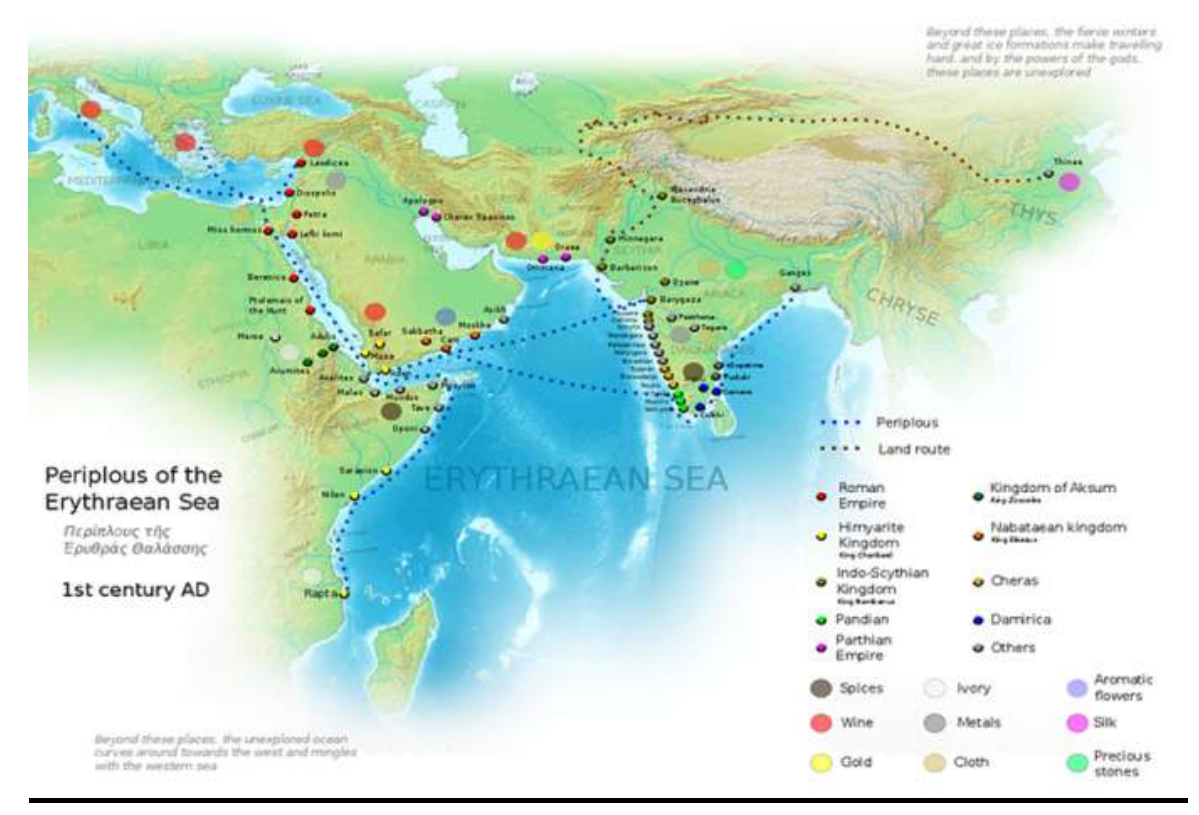

Source: https://www.ancient.eu/image/9102/ancient-indian-maritime-trade-routes/

The above map, Fig 2, has been depicted in the book titled "Periplus of the Erythraean Sea". Tsiagalskis (2018) highlights how "Trade routes in the ancient world, ports in the Chera territory and other parts of India and the trade routes connecting them to other parts of the world along with the items of trade" existed in ancient times. The New World Encyclopaedia (NEW, n.d) describes the Periplus:

The Periplus of the Erythraean Sea or Periplus Maris Erythraei was written sometime between the 1st and 3rd centuries CE (Common Era-Gregorian Calendar), by an unknown Greek author. It is sort of a marine guidebook, based on the records of the author, an experienced sailor, who navigated the Red Sea, Persian Gulf and the Indian coasts of Kerala and Coromandel (eastern coast) and stayed for many years at the western Indian port of Barygaza-Broach.

The Periplus Maris Erythraei describes Greco-Roman merchants selling in Barbaricum thin clothing, figured linens, topaz, coral, storax, frankincense, vessels of glass, silver and gold plates, and a little wine in exchange for costus, bdellium, lycium, nard, turquoise, lapis lazuli, Seric skins, cotton cloth, silk yarn, and indigo. In Barygaza, they would buy wheat, rice, sesame oil, cotton and cloth. Some of the major regional ports which significantly contributed to the 
ancient Indian Maritime trade were Barbaricum (modern Karachi), Sounagoura (central Bangladesh) Barygaza, Muziris in Kerala, Korkai, Kaveripattinam and Arikamedu on the southern tip of present-day India and were the main centres of this trade, along with Kodumanal, an inland city.

Maritime history scholars like Daggett (Daggett, 2016) explain that by 3000 BC, small rafts and canoes traversed the coastal sea from Arabia to Indian Subcontinent and millet and sorghum imported from East Africa even reached the Harappan people by 2000 BC. He points out:

Archaeological evidence and genetic studies suggest that the first major settlement of Madagascar came not from Africa - a short hop across the Mozambique Channel but from Indonesia, 4,000 miles away. Many of these goods made their way far inland. Archaeologists today regularly recover small items like glass beads, spindle whorls or Chinese porcelain at sites across Africa and the Mediterranean. These foreign-made objects - particularly those easily transported, such as glass beads — became a kind of currency in more ways than one.

As Daggett (Daggett, 2016a) noted, “It wasn't like money, though you could say beads the length of your arm would get you a cow, or a certain number of chickens"........"Though it created a form of wealth and power. It built alliances". However, determining value of the trade would not be feasible due to lack of authentic records.

It is important to note that Indian Ocean trade never truly disappeared, as one would imagine. When industrial revolution dawned on Europe, the expansion of European explorations into the Orient and the withdrawal of China from international affairs merely resulted in the world's economic focus shifting from the East to the West. In the centuries that followed,

Colonial domination and westernization of education system in the East perhaps led to few researchers studying this early and extensive trade network. Sadly, it were the Europeans who wrote the histories, including that of India. Thus, authenticated history of India's ancient maritime trade is still a bit of a mystery. But the far and wide reach of Indian Traders has significant importance in India's claims in the maritime domain and free passage in South China Sea. 


\section{India and South China Sea}

India's connection with SCS region spans the cultural, economic and diaspora dimensions. For thousands of years now, Indian culture has reached out to Southeast Asia over land and sea. The eight hundred year old Angkor Wat temple complex is a living example of Indian civilization's reach into that region. Rajaraja and Narasimha Varma of Chola and Pallava dynasties of South India had sent cultural embassies even to the Emperor of China. They had even sent their navies into SCS region to protect their trade interests since the cotton trade from India reached out to all these parts extensively. In the process of these peaceful interactions, thousands of India tradesmen (traders, artists, smiths, etc) had found their home in Southeast Asian region. Indian culture took deep roots in the region since it came without political strings (Sardesai, 2010).

In the modern era, India's trade with ASEAN, Japan and Americas (North and South) is dependent upon and passes through SCS. As Ghokale (2020a) points out:

...this sea would also be strategically important for India as nearly $\$ 200$ billion of Indian trade passes through the South China Sea and thousands of Indian citizens study, work and invest in ASEAN, China, Japan and the Republic of Korea. India has also stakes in the peace and security of this region, in common with others who reside there, and freedom of navigation. Freedom for conducting other normal activities with friendly countries would also be essential for India's economic well-being.

In short, the South China Sea needs to firmly remain as India's business. India has historical rights established by practice and tradition to traverse the South China Sea without impediment.

Seen from the diaspora connection too, developments in SCS would have critical and important implications for India's wellbeing. From the age old peaceful cultural connection Southeast Asian nations have cooperated with India for over two thousand years, to create prosperity in the region and still continue to do so. China's contention that these nations, including India, who have had historically unimpeded rights for trade and other peaceful purposes, are somehow outsiders and should not be permitted to engage in legitimate activity in the South 
China Sea, or have a voice without China's say, is obnoxious and devoid of legal and moral merits.

It is noteworthy that ASEAN members have always welcomed India's presence in Indo Pacific region in general and in South China Sea in particular as they see it as a potent counterbalance to China. But India needs to realise that the expectations of ASEAN members needs to be met with firm cooperative agenda and with dated objectives.

\section{Current Maritime Trade Scenario}

Analysis of the available trade data has shown that currently about $90 \%$ of world trade is carried through the Sea routes. Accordingly, shipping has become life line for the global economy. Without shipping infrastructure, no operations comprising intercontinental trade, bulk transport of raw materials, and the import/export of affordable food, manufactured goods and petroleum products would be feasible. ICS (ICS 2020) has observed that "matters related to unhindered Maritime Trade, protecting Maritime Boundaries and safeguarding Sea Lines of Communication (SLOCs) have thus assumed considerable importance". It may be noted that currently annual Indian Maritime Trade has been valued at USD 851 Billion (Equitymaster, 2020).

\section{Part 2: Global Perspective-South China Sea Dispute}

In July 2016, the Permanent Court of Arbitration at The Hague issued its ruling on a claim brought against China by the Philippines under UNCLOS, ruling in favour of the Philippines on almost every count (PCA, n.d). While China has been a signatory to the treaty establishing the tribunal, it has refused to accept the court's authority. Beyond such refusal to comply with international law, China has also aggressively started building artificial islands, as evident from AMTI (AMTI, n.d) that states:

In recent years, satellite imagery has shown China's increased efforts to reclaim land in the South China Sea by physically increasing the size of islands or creating new islands altogether. In addition to piling sand onto existing reefs, China has constructed ports, military installations, and airstrips - particularly in the Parcel and Spratly Islands, where it has twenty and seven outposts, respectively. 
Another observer Bitzinger (Bitzinger 2018) also reports, "China has militarized Woody Island by deploying fighter jets, cruise missiles, and a radar system". The above activities have posed threats to stability and economic wellbeing of the countries in the region.

A broad analysis of the current situation in the South China Sea has revealed that China has very smartly used ambiguous SLOC to their, though very unfair, advantage. Scholars of the Tuft University (TFS, n.d) stated that:

"The increasing risk of conflict in the South China Sea (SCS) poses a significant threat to stability in the region and to U.S. interests. Not only do Taiwan, Vietnam, Malaysia, Brunei, and the Philippines have competing territorial and jurisdictional claims over the physical features of the SCS, but U.S. Freedom of Navigation (FON) operations have also elicited an increasingly hostile tone from Beijing. They have also pointed out that Beijing's insistence that it has "indisputable sovereignty over the South China Sea Islands and the adjacent waters" within the so-called "nine-dash line" as well as its accelerated industrial scale "island building" for military purposes have increased the overall international tensions and resentments in this region.

The implications of this feverish island building has the effect of expanding Chinese EEZ, intruding into the zones claimed by other littoral countries like Philippines. Under the ambiguous UNCLOS interpretations countries with EEZ claims can also carry out their own military activities without notifying other littorals. This ambiguity sits in favour of China which has far superior military muscle than any of the other littoral countries. The Council of Foreign Relations (CFR, n.d.) analysis very rightly points out that:

"SCS contains many maritime features that may or may not be islands entitled to large EEZs. Even small islands, such as the Spratly Islands, which total 1.5 square miles in size, can project hundreds of square nautical miles of exclusive economic control over the South China Sea".

Under international law, foreign militaries would not able to conduct intelligencegathering activities, such as reconnaissance flights, in its exclusive economic zone (EEZ). According to the United States, claimant countries, under UN Convention 
of the Law of the Sea (UNCLOS), should have freedom of navigation through EEZs in the sea and are not required to notify other claimants of military activities.

It is evident that China has been the originator of this dispute. Unfair claims of China related to its sovereignty over the sea coupled with its economic interest in estimated 11 billion barrels of untapped oil along with 190 trillion cubic feet of natural gas in SCS have resulted in antagonising other rightful claimants like Brunei, Indonesia, Malaysia, the Philippines, Taiwan, and Vietnam. Since 1970s these countries began to claim islands and various zones in the South China Sea, such as the Spratly Islands, which possess rich natural resources and fish.

The United States has challenged China's assertive territorial claims and land reclamation efforts by conducting FONOPs (Freedom of Navigation Operations) to safeguard its political, security, and economic interests in the region. The United States action is also aimed at bolstering support for "Southeast Asian partners" (Smith, 2018). Japan has stepped out to sell military hardware (ships and equipment) to SCS littorals like Philippines and Vietnam "in order to improve their maritime security capacity and to deter Chinese aggression". (Hart, 2017).

\section{Major Global Concerns}

Washington's concerns over the developments in SCS are three fold: first, America's own trade interest that centre on SCS; second, as the as-yet-unchallenged global power with huge interests in promoting rule of law; and third, its obligations to protect the sovereignty and economic interests of its allies in the Pacific. These concerns were amply reflected by Mr David R Stilwell, The Assistant Secretary Bureau of East Asian and Pacific Affairs in his address at an event at Center for Strategic and International Studies -USA where he (Stilwell, 2020a) stated that:

By claiming indisputable sovereignty" over an area larger than the Mediterranean and trampling the rights of others, Beijing has threatened the existing order that has given Asia decades of prosperity. That order has been based on freedom and openness, ideas that Beijing opposes. 
...nearly $\$ 4$ trillion in trade transited the South China Sea each year and more than $\$ 1$ trillion of that was linked to the U.S. market. He highlighted that the South China Sea was home to an estimated $\$ 2.6$ trillion in recoverable offshore oil and gas. It also has some of the world's richest fishing grounds, which employed an estimated 3.7 million people in coastal Southeast Asian states. In his address he also opined that "these resources were the birth right of Southeast Asian nations, the lifeblood of their coastal communities, and the livelihood of millions of their citizens. They were the inheritance of each nation's children and grandchildren. Beijing's behaviour was an assault on the people of Southeast Asia today, and from generation to generation.

A scan of the current situation in the South China Sea would reveal that the Unite States, which has economic and security interest in the region has very strongly propagated the necessity for freedom of navigation and securing the sea lines of communication (SLOCS). It has supported an agreement related to promulgation of a "binding code of conduct" and instituting other confidence building measures. USA is certainly concerned about the China's unfair claims in SCS which jeopardises security of SLOCS- important for free movement of merchant and naval vessels. Undoubtedly USA has an important role to play in SCS is ensuring safety, security and peace in this region.

Washington's defence treaty with Manila could draw the United States into a potential China-Philippines conflict, over the substantial natural gas deposits or lucrative fishing grounds in the disputed territory. The failure of Chinese and Southeast Asian leaders to resolve the disputes by diplomatic means could also undermine international laws governing maritime disputes and encourage destabilizing arms build-up (CFR, n.d).

Further, the immense maritime wealth on which China is trying to lay a sole claim has also been a matter of global concern. Researchers have pointed out that, "China has unfairly exploited an incentive for states to obtain island status for their deep ocean features" (TFS, n.d)

China's stand that the world must accept its sole claim on vast Maritime wealth and territorial supremacy in the South China Sea has been considered extremely unfair. This has been attributed to the fact that all the countries in the region rely upon those resources, as well as free passage for their maritime trade, a vital factor for strengthening their stressed economies. 
A hearing conducted by the 'Subcommittee on East Asian and Pacific Affairs, of The Committee on Foreign Relations (United States Senate)' on developments in the South China Sea revealed that the key claims focused on the Spratly Islands, comprising 21 islands and atolls, 50 submerged land atolls, and 28 partially submerged reefs. Though their total land mass was small, they were spread out over 340,000 square miles. Hearings also revealed that China and Vietnam had also laid conflicting claims on the "Paracels, a smaller group of islands, located south of China's Hainan Island" (Stilwell, 2020, July 14).

The discussions in the Subcommittee point to the inevitability of American involvement to counter the imbalance of power that China has brought to bear on other countries. The American involvement however, has to take into consideration the threat perceptions of each of the other countries and the course of action they are willing to take to protect their interests.

However, China seems to have demonstrated its willingness to display new military capabilities, and at times to use force to claim undeserved maritime territory. China's move of detaining Vietnamese fishermen near the Paracel Islands, and its overt threats to United States oil companies operating in the South China Sea are some examples. It was also observed that China has been increasingly using its artificial islands as bases for harassment operations like curtailing fair access of Southeast Asian coastal states to offshore oil, gas and fisheries.

These incidences highlight China's intentions and the increased risks to shipping and fishing, and the limited prospects, resource exploitation. It can be concluded in no uncertain terms, that if above China's actions are not countered, they may threaten the well-being of the whole region. In response, other countries in the region were forced to modernize their naval capabilities, thereby leading to avoidable arms build-up.

It is thus clear that USA/India/South East Asian Counties would need to unite and thwart the unfair Chinese ambitions of unilaterally controlling the South China Sea and ruining the wellbeing and security of the nations in that region. 


\section{Part 3: South China Sea Dispute- Implications for India}

\section{Understanding China's Psyche}

Before we delve into India's interests in South China Sea Dispute, it would be important to understand psyche of China, which affects Sino-Indian relations. India and China have shared thousands years of cultural and trade relations. Overland routes and maritime routes that connected both the countries have also been the channel through which Buddhism also travelled from India and took root in China. Even though such cultural connectivity led to a presumption of India being a paradise of knowledge and philosophy, scholars like S Saran (Saran, 2020) observe that:

This (presumption) challenged the notion of Chinese centrality and was for this reason rejected by intellectuals at times as an alien influence, but this did not prevent its embrace by the populace as a comforting faith. These inter-connections were often interrupted by political turmoil and transitions in both countries as well as in intermediary realms.

This interruptive phenomenon unfortunately exists even today. An analysis of Sino-Indian relations over past decades point to an interesting fact. Whenever the relations were in a positive phase China has been reflecting on Buddhist heritage and trade and cultural exchange between the countries. References to mutual sympathy and support during the more contemporary period of India's struggle for independence and China's liberation are also seen. However, "whenever relations became strained and contentious, negative narratives surface not only in Chinese media but also in statements by the Chinese leaders" (Saran 2020 ibid). China's use of abusive language and uncharitable comments by the Chinese leaders, post recent clashes in Eastern Ladakh region would prove the point. Similar strategies have been used by China with many other nations, thereby creating an enigma of challenges, keeping the rest of the world guessing and on tenterhooks.

China's moves on India's eastern borders, heightened activities on Bhutanese borders and claims over Nepalese territory recently have sent alarm bells ringing in New Delhi. Even though Hambantota has nearly become a case study for Debt Trap Diplomacy, China's relations with 
Sri Lanka and Bangladesh; presence of Chinese ships for allegedly hydrographic surveys in Sri Lankan waters and Indian Ocean appear to compound such alarms.

Further an attempt to analyse China's moves in SCS prima-facie indicates China's desire for territorial and economic dominance, technological supremacy in a tussle for greater power with USA. But a deeper analysis would point to a big strategic error in attributing the China's behaviour as merely a clash of interests as it is, in reality, more than that. Historical facts have proven that The Communist Party of China (CPC) has mostly been against the "individual freedom of thought" (Pai, 15 September 2020) which many other nations strive to protect. The impact this threat can have on the prevailing international system, national governments, markets, individuals, civil societies and technology, cyber and geography cannot be overlooked.

China expects the whole world to accept its strategies to constrain what world generally admits as acceptable thinking, speech and action. This methodology, adroitly exploited by China underlies the South China Sea dispute and China's behaviour with India. It is evident that the aggressive moves in India's own borders coupled with the threat to international system and order have huge implications for India.

\section{India's connect with South China Sea Dispute}

As discussed earlier, India's has substantial historical and current cultural, economic and diaspora interests in the SCS littoral region. Increasing trade and strategic interests as an emerging power in the global arena makes it imperative that India's role in SCS needs to be appreciated comprehensively. Maritime Analysts Puri and Sahgal (Puri \& Sahgal 2011) looking into the situation is South China Sea in relation to India and feel that:

"The fundamental perspective of Indian interest in the South China Sea has been underscored by the growing arc of Indian strategic interests in tune with its increasing trade and economic engagements. ASEAN and East Asia form the fastest growing component of India's economic interests and an area of acute geo-political and strategic interest. This has led to strategically linking the ocean spaces of the Indian Ocean and Pacific Ocean; a term has been coined - the Indo-Pacific Ocean - to highlight seamless connectivity. It is, therefore, but natural that Indian interests will gravitate toward the security and stability of this expanded geo-economic and geo-political space at the 
confluence of the two major oceans. The extension of Indian strategic space into the Indo-Pacific Ocean will naturally have strategic consequences".

China feels that it must have unchallenged supremacy in South China Sea as it sees it as a instrument for power projection in Asia-Pacifica region. Thus China, unfairly, sees India's presence as a move to contain China in collaboration with like minder countries in the region, while continuing with hegemonic behaviour.

It is very unfortunate that India's growing bilateral relations with Vietnam and with other SouthEast Asian countries, in particular Indonesia, and growing strategic cooperation with Australia and Japan, are branded by the China as an Indian attempt at strategic assertion in the Chinese backyard, while asserting its own freedom of pursuing its own foreign policy- an unprincipled display of double standards.

Many analysts have acknowledged India's geo-politico-economic interests in South China Sea. It would be interesting to note that China had never formally objected to any of the agreements or projects undertaken by India till it became assertive over SCS in recent years. With India's policy of non-aggression, it would not lead to a direct confrontation with China; but it cannot forsake its legitimate economic rights and agreements entered with the other sovereign governments like ASEAN, Australia, Japan and even the US - to develop maritime cooperation. Thus If China insists upon coercing India, then it would be prudent for India to raise the issue of Chinese presence in Pakistan (Puri \& Sahgal ibid), where the China has been dabbling in more that forty five projects ( with cumulative investment of about \$ 8-10 billion) through China Pakistan Economic Corridor (CPEC) and Belt and Road Initiative (BRI).

India also needs to leverage its BIMSTEC initiative, comprising of seven states from South Asia and two states from South East Asia. S Ramachandran (Ramachandran, 2019) has stated that "Importantly, with the exception of India and Bhutan, the other BIMSTEC members are participating in China's Belt and Road Initiative (BRI)." It is, therefore, important for India to maintain not only good neighbourly relations with the BIMSTEC partners but also maintain overarching trade/financial/military/cultural relationships. This would be important from the angle of having a good back up strategy to counter China's hegemonic and coercive attitude. 
With its stature as a rising power with a relatively well preforming economy-the 7 th world economy in terms of a GDP of around \$2 trillion according to the World Bank-, a member of the Global South, actively involved in multilateral fora such as the BRICS and G20, a cofounder of the Asian Infrastructure Investment Bank (AIIB), India has a significant role to play in geo-politico-economic security of the Asian region. Many nations in the region expect India's support for safeguarding their interest. India's position in Indian Ocean Region (IOR), Southeast Asia, East Asia and the Asian Pacific countries and its influence, especially in terms of global governance and international security has made it a regional power to look up to (Granados 2018).

Further, since inception of Look East Policy's (LEP) India has been seen as a power capable of providing politico-economic security by the Asian and Asia-Pacific countries looking for more cooperation, trade and investment. Later with Act East Policy (AEP) India had to start focusing on multilateral links with ASEAN nations, the United States and Japan. To meet its geopolitico-economic security economic India has to preserve unhindered access to the sea lines of communication in the IOR and Southeast Asia, thus promoting freedom of navigation as one of its core national interests.

As a corollary, free navigation in the South China Sea, where around 55 per cent of India's trade transits has become very important for the functioning of the AEP. In addition stability in this region has also assumed paramount importance for India in the interest of its national security. Thus India's geo-politico-economic interests clash with China's territorial claims and India cannot afford to give-in to China's whims and fancies.

\section{India's Response to South China Sea Situation}

India, keeping in mind in its own national interests had to charter it own course in maintaining its international relationships. In order to reduce China's influence in Asia, India had to not only engage the United States but also pursue an effective Look/Act East Policies. These relationships which have gradually become increasingly strategic in nature; intensifying ties with certain ASEAN member states and with China's main East Asian rival, Japan. With increasing bonhomie with the US, 'strategic triangle' of China-India-US relations has undergone major changes and India has been preparing to face the consequences. 
Adhering to the age-old precept of 'the enemy of my enemy is my friend', India has stepped up its military ties with countries traditionally wary of China's power in the region, such as Vietnam, and, looking even further afield, to Mongolia. India has also improved its bilateral ties with Australia and Japan. In this regard, QUAD (USA/Australia Japan/India) has been a welcome step towards stemming the dragon's unwarranted belligerence. But the Quad will need to have a clearer vision for itself. It would be important for members of the Quad not to be reactive and to exhibit openness, and ensure that all talk of a 'Free and Open IndoPacific' would prove more than just a mere slogan and would succeed in taming the fire spewing Dragon.

One important factor to which India should pay more attention is strengthening its BIMSTEC initiative to work as a force multiplier for all the participating nations thus forming an effective buffer against China's belligerent behaviour.

Fortunately, India has now begun to better appreciate multipronged threats posed, to its geopolitico-economic security as well as to overall stability in Asia Pacific Region, by belligerent and coercive attitude of China. To counter the same India has decided to step out of its own shadow and put in place effective measures to counter China's hegemonic manoeuvres.

\section{Suggestive Response Strategy Construct - The First Pressure Point}

It is important to appreciate that the economic, trade and security risks which have been escalated by China's belligerence have had destabilising effect on the global stability. An effective response strategy to counter Chinese coercion and strategic outstretch would be thus a time-critical global imperative.

AB Shivane (Shivane, 2020) has suggested that the foundational construct of this strategy needs to pitch the coordinated global strength to take advantage of the opportunities in terms of collective economic decoupling, pandemic accountability, and coordinated security partnerships, both at the bilateral and multilateral level. The cost-benefit of Chinese coercion and territorial cum maritime quest must be made cost-prohibitive by targeting the two primary areas of exploiting its economic vulnerability and igniting a global backlash. He recommends that the contours of a sustained and coordinated global effort to counter China's nefarious designs must include the following:- 
a) Isolating China- A global dissuasion campaign highlighting the high risk and negative consequences of doing business with the Dragon must find global focus. It must infuse a coordinated political, economic, diplomatic and military coordinated response mechanism both against China and its allies. Obscuring the origin and handling of Pandemic is another area which must seek responsibility and accountability.

b) Economic Decoupling to Economic Divorce- This is a double-edged strategy as it would entail systemic risks with global supply chains and manufacturing industry centred on China. China has leveraged this economic grip to weaponize trade. Ironically, it also remains its greatest vulnerability which can be the key to the response strategy, minimizing risks by alternate global economic cooperative mechanisms and generating more lucrative options.

c) Geopolitical Backlash Cost against Repression- Chinese human right violations and repression on its periphery, particularly Hong Kong, Tibet, Mongolia and communal atrocities in Xinjiang besides the internal suppression of freedom of expression/dissent must find global vocal cord and sanctions. Taiwan must also gain enhanced sympathy and support. Thus exposing and leveraging Chinese fault lines would raise the cost of its coercion and overstretch by inviting a global backlash.

d) Global Security Collaboration for Strategic Stability- China's illegal seizure of most of the South China Sea and intrusions in the Himalayas mandates a global security response. While the battle in the mountains is being fought well by boots on ground aided by technology and modern weapon systems; it is in the maritime domain wherein global strategic security interests converge and will make China feel the heat. Thus global maritime security cooperation and partnerships both at the bilateral and multilateral level are garnering impetus. India by its geographical location and peninsular gifted disposition will always be central to such partnerships. China must also realise that an antagonist and overstretched China will expose the vulnerabilities of its overextended lines of communication to interdiction both on land and at sea.

"China must be made to face the dilemma and consequence of its coercive strategy and overextension by targeting its multi-point multi-front vulnerabilities through a calibrated global 
response strategy. The Dragon must feel the heat and be made to recoil and reform." said Shivane.

\section{India's Strategic Dilemma relating to Firm Actions in South China Sea Region}

From the above analysis it is quite clear that India needs to be cognisant of unavoidable requirements of protecting of its geo-politico-economic interests, supporting South East Asian nations in protecting their wellbeing and stemming increasing belligerence of China by taking hard stance. But it would be much easier said than done. Analysts like A Singh (Singh, 2016) point out:

For the Indian Government, the events in South China Sea have always underscored the contested nature of maritime politics in the Pacific. China and the U.S. play the ritual of cooperation and conflict at sea with a practiced ease that is hard to overlook. Just days after the passage of the Curtis Wilbur for the second FONOPS, the U.S. Chief of Naval Operations consulted with his Chinese counterpart about unplanned encounters at sea. Both naval chiefs appeared satisfied with the implementation of the code. Yet, only a few days later, China had placed missiles on the Woody, and Admiral Harry Harris, the commander of U.S. Pacific Command, promptly announced that the security situation had worsened to a point where the USN was contemplating intensifying the FONOPS.

On same note the USA and China are currently a playing a 'trade sanctions game', but finally what shape it would take and what implications it would have for India only time will tell.

On the whole, India's inevitable involvement in various global developments have constrained India to strike a balance between its maritime security imperatives in the Indian Ocean, and its legal stance on freedoms enjoyed by user states in territorial waters. As Singh says, "India's real dilemma rises from the fact that while it opposes Chinese aggression in the South China Sea, it also disagrees with Washington's interpretation of maritime law and the freedoms enjoyed by foreign warships in littoral spaces" (Singh 2016a).

Like China, India too rejects the right of innocent passage by warships through EEZ of any nation without prior notification and consent of that nation. Even though such passage may be within the UNCLOS framework, New Delhi considers it's a challenging proposition impinging on sovereignty. The difference between India and China on this aspect however is that India holds it as an universal principle whereas China excludes itself from such an interpretation. 
Such a stance by India has a potential clash of interests in Andaman Sea where China uses the same interpretation to freely send its vessels. Notwithstanding China's objections the recent QUAD Naval Drills in Arabian Sea and Bay of Bengal are perhaps aimed at sending a clear message to China to fall in line within international order, even though it may appear as being supportive of US position on territorial disputes. Rightfully, observers like T Bose (Bose, 2020) have addressed this dimension also in these words:

India needs to ask itself whether the policy of closer alignment with the United States (US), along the policy path that India is already pursuing, is the best way to meet the challenges posed by China. The Modi government needs to examine the real capacity of the US to deliver active military assistance to India in the event of a war with China. Despite the US-Japan Security Treaty that enjoins the US to come to Japan's military defence if it comes under attack, the US did not come to Japan's aid in the latter's ongoing dispute with China over the Senkaku/Diaoyu islands. In fact, the US even refused to recognise Japan's sovereignty over the islands for fear of getting embroiled in a military conflict. India would also need to weigh the impact of its closeness to USA on its ties with its all-weather friend-Russia.

In additions to above, it would be difficult for India to execute financial gunboat diplomacy like China, to make the dependent states tow its line. India's internal situation, comparative preparedness of its armed forces, Covid-19 impact on its economy, troubled political atmosphere and intertwined business relationships with China may very much curtail India's options, and force it to be cautious in its approach towards China and its South China Sea strategy. The Indian government thus stands in an unenviable position and would need to do some real 'out of the box' thinking to find a workable solution.

\section{Part 4: Conclusion and Recommendations}

\section{South China Sea Dispute}

India for far too long has been soft on China and China has been taking undue advantages of India's friendship and decency. China has always displayed its unreliable nature from its actions- bonhomie \& 1962, bonhomie \& Doklam, bonhomie \& Ladakh, - India needs to tell China in no uncertain terms that "enough is enough". 
Time has now come for India to have a more aggressive and consistent strategic policy to tackle China. It is, therefore, recommended that India may:-

a) Strengthen ASEAN and make it a power to reckon with, through a constructive engagement with the South East Asian nations and helping them to bolster their economies and assisting then in enhancing their national security.

b) Strengthen the BIMSTEC alliance by furthering the economic and cultural relations with the partners and creating an effective soft buffer between India and China.

c) Improve efficacy of QUAD by proactively engaging with the QUAD partners (Australia, Japan. USA) and create a strong counter to China's belligerence in South China Sea, without jeopardizing its own interests in the IOR.

d) Put measures in place to reduce the internal strife, build political consensus and revive the economy on fast track and resolve and settle the Sir Creek dispute, as China may use its leverage, through CEPC and BRI on Pakistan to create unacceptable situation for India turning the simmering bilateral dispute in a multilateral imbroglio.

e) Initiate expeditious action to modernize its armed forces making them potent deterrent force, thus increasing the costs both China and Pakistan would need to pay to unacceptable levels, for their misadventures on land, in Seas, in air.

It is understood that above would warrant some out of the box thinking by the government and have significant financial ramifications but it is need of the hour, as India is standing at cusp of now or never situation.

Finally, some lingering questions do remain unanswered. A few questions finding answer to which would need further research cover:-

a) Post Presidential Power Change over in Jan 2021, in USA, what scenario India would need to face? What would be the impact on USA-China and Indo-Russia relations? What will be the future of QUAD?

b) How Pakistan would react to all the initiatives taken by India to thwart the belligerence of China, as they would have a direct impact on geo-politico-economic situation of Pakistan. 
c) Last but not the least, how would China's claim that Vladivostok and neighbouring areas were part of China, affect Sino-Russian Relations and what impact it will have on India?

\section{Acknowledgment:}

The author would like put on record his thanks to MPIDSA for valuable article support, Dr R Srinivasan for timely support and guidance during sometimes tumultuous journey and Mrs Sujata Deshmukh for constant motivation and excellent logistical support.

\section{References:}

"Sanskrit Quote" retrieved from https://sanskrits.xyz/sanskrit-mottos-sanskrit-sloganstagline/, Accessed on 14 Dec 2020

Lal, Avantika (15 Aug 2015). Ancient History Encyclopaedia, Naval Warfare in Ancient India, retrieved from https://www.ancient.eu/article/1259/naval-warfare-in-ancient-india/ accessed on 08 Oct 2020

Gilbert, Gregory P (2007). Sea Power Centre Australia, Ancient Egyptian Sea Power and the Origin of Maritime Forces, Retrieved from https://www.navy.gov.au/sites/default/files/documents/IntSP_1_Ancient_EgyptSP.pdf Accessed on 08 Oct 2020 pages 9 to 11

Britannica Encyclopaedia (2020). Encyclopaedia Britannica, Achaemenian Dynasty Iranian Dynasty, retrieved from https://www.britannica.com/topic/Achaemenian-dynasty Accessed on 08 Oct 2020

Phillips, T., Holmes, O., \& Bowcott, O. (2016, July 12). Beijing rejects tribunal's ruling in South China Sea case. The Guardian. Retrieved from: https://www.theguardian.com/world/2016/jul/12/philippines-wins-south-china-sea-caseagainst-china. Accessed on 30 Sep 2020

MI, N. N. (2018, November 4). Maritime Silk Routes- The Story of the Oldest Trade Routes. Marine Insight. https://www.marineinsight.com/maritime-history/maritime-silk-routes-thestory-of-the-oldest-trade-routes/, Accessed 30 September 2020.

Tsiagalakis, G. (2018, August 15). Ancient Indian Maritime Trade Routes. Ancient History Encyclopaedia. https://www.ancient.eu/image/9102/ancient-indian-maritime-trade-routes/. Accessed 29 September 2020.

NWE. (n.d.). Roman trade with India, New World Encyclopedia. Retrieved from https://www.newworldencyclopedia.org/entry/Roman_trade_with_India. Accessed 04 October 2020. 
Daggett, A. (2016, October 20). The Indian Ocean: A Maritime Trade Network History Nearly Forgot. Discover Magazine. https://www.discovermagazine.com/planet-earth/theindian-ocean-a-maritime-trade-network-history-nearly-forgot. Accessed 28/29 September 2020 .

Daggett, A. (2016a, October 20). The Indian Ocean: A Maritime Trade Network History Nearly Forgot. Discover Magazine. https://www.discovermagazine.com/planet-earth/theindian-ocean-a-maritime-trade-network-history-nearly-forgot. Accessed 28/29 September 2020.

ICS. (2020). ICS | Key Facts. Retrieved October 4, 2020, from https://www.icsshipping.org/shipping-facts/key-facts. Accessed 29/30 September 2020.

Equitymaster. (2020, January 22). Indian Shipping Industry Report—Shipping Sector Research \& Analysis in India-Equitymaster. https://www.equitymaster.com/researchit/sector-info/ship/Shipping-Sector-Analysis-Report.asp. Accessed 29 September 2020.

Guo, R. (2018a). Cross-Border Resource Management. Elsevier. https://doi.org/10.1016/C2016-0-04674-0. Accessed 28/29 September 2020.

Guo, R. (2018b). Chapter 12-Cross-Border Conflict Prevention and Management. In R. Guo (Ed.), Cross-Border Resource Management (Third Edition) (pp. 337-386). Elsevier. https://doi.org/10.1016/B978-0-444-64002-4.00012-X. Accessed 28/29 September 2020.

Tufts University Report, retrieved from https://sites.tufts.edu/lawofthesea/chapter-two/ Accessed on 29 sewp 2020

UNCTAD. (n.d.). UNCTAD | Oceans Economy and Fisheries. Retrieved from https://unctad.org/en/Pages/DITC/Trade-and-Environment/Oceans-Economy.aspx. Accessed 04 October 2020.

Belt and Road News (30 Nov 2019). beltandroad.news Retrieved from: www.belrandroad,news/2019/11/30/chinas-belt-road-resume-ancient-trade-routes-as-silkroads/ Accessed on 12 Oct 2020

Belt and Road News (30 Nov 2019a). Retrieved from: www.belrandroad,news/2019/11/30/chinas-belt-road-resume-ancient-trade-routes-as-silkroads/ Accessed on 12 Oct 2020

TFS (n.d), Tufts University, Chapter 10- The South China Sea Tribunal. Laws of the Sea-A policy primer, retrieved from https://sites.tufts.edu/lawofthesea/chapter-ten/ Accessed on 08 Oct 2020

CFR. (n.d.). Territorial Disputes in the South China Sea. Global Conflict Tracker. Retrieved from O https://www.cfr.org/global-conflict-tracker/conflict/territorial-disputes-south-chinasea Accessed on 29 September and 04 Oct 2020. 
PCA. (n.d.). Cases | PCA-CPA. Retrieved October 7, 2020, from https://pcacpa.org/en/cases/7/. Accessed 04 October 2020.

AMTI. (n.d.). China Tracker. Asia Maritime Transparency Initiative. Retrieved October 7, 2020, from https://amti.csis.org/island-tracker/china/ Accessed 28 September 2020.

Bitzinger, R. A. (2018, May 9). Why Beijing is militarizing the South China Sea. Asia Times. https://asiatimes.com/2018/05/why-beijing-is-militarizing-the-south-china-sea/. Accessed 29 September 2020.

Smith, J., M. (2018, March 14). Unpacking the Free and Open Indo-Pacific. War on the Rocks. https://warontherocks.com/2018/03/unpacking-the-free-and-open-indo-pacific/. Accessed 30 September 2020).

Hart, M. (2017, August 29). Japan's maritime diplomacy mission in S.E. Asia|The Japan Times. https://www.japantimes.co.jp/opinion/2017/08/29/commentary/japancommentary/japans-maritime-diplomacy-mission-s-e-asia/. Accessed 02 October 2020.

Report Hearings before the Subcommittee on East Asian and Pacific Affairs of the Committee on Foreign Relations United States Senate $111^{\text {th }}$ Congress, First Session. 15 Jul 2009. Retrieved from: https://www.govinfo.gov/content/pkg/CHRG-111shrg53022/html/CHRG111shrg53022.htm Accessed on 08 Oct 2020

Stilwell, D. R. (2020, July 14). The South China Sea, Southeast Asia's Patrimony, and Everybody's Own Backyard. United States Department of State. https://www.state.gov/thesouth-china-sea-southeast-asias-patrimony-and-everybodys-own-backyard/ Accessed 08 October 2020.

Stilwell, D. R. (2020, July 14a). The South China Sea, Southeast Asia's Patrimony, and Everybody's Own Backyard. United States Department of State. https://www.state.gov/thesouth-china-sea-southeast-asias-patrimony-and-everybodys-own-backyard/ Accessed 08 October 2020.

Shyam Saran, 08 October 2020,The Print, China looked at India under British rule as a teacher - of what not to be, Retrieved from https://theprint.in/opinion/china-looked-at-indiaunder-british-rule-as-teacher-of-what-not-to-be/519648/ Accessed on 12 Oct 2020

Nitin Pai (15 September 2020). The Print, China is an enemy of freedom of thought. It wants the same from other powerful nations Retrieved from: https://theprint.in/opinion/china-is-anenemy-of-freedom-of-thought-it-wants-the-same-from-other-powerful-nations/502708/?amp. Accessed on 12 Oct 2020

Sardesai, D.R. (2010). Southeast Asia: Past and Present, Westview Press: Boulder, p. 17

Gokhale, V. (2020a, b \& c. June 16). How the South China Sea situation plays out will be critical for India's security $\mid$ The Indian Express.

https://indianexpress.com/article/opinion/columns/south-china-sea-dispute-asean-countriesrelations-vijay-gokhale-6460680/. Accessed 28/29 September 2020. 
Puri Raman and Sahgal Arun (Oct 2011). Indian Foreign Affairs Journal (Vol 6, No 4, Oct Dec 2011) Retrieved from http://www.associationdiplomats.org/Publications/ifaj/Vol6/6.4/ARTICLE\%203.pdf. Accessed on 12 Oct 2020.

Ramachandran Sudha (31 May 2019). The Diplomat, India's BIMSTEC Gambit stalled. India is turning to BIMSTEC to center its foreign policy. Retrieved from:

https://thediplomat.com/2019/05/indias-bimstec-gambit/ Accessed on 11 Oct 2020

Granados, Ulises (22 Jan 2018). India's Approaches to the South China Sea: Priorities and Balances, Asia \& Pacific Studies, Vol 5 Issue 1, January 2018, Pp 122-137. Published by Australian National University, Retrieved from https://onlinelibrary.wiley.com/doi/full/10.1002/app5.223. Accessed on 08 Oct 2020.

Muhammad Ali, Dec 2012, Naval Post Graduate School, California, Maritime Issues between Pakistan and India: Seeking Cooperation and Regional Stability. Retrieved from: https://www.google.com/search?q=sir+crrek+naval+thesis+ali\&rlz=1C1RXQR_enIN931IN9 $31 \&$ oq $=$ sir + crrek + naval+thesis+ali\&aqs $=$ chrome $.69 i 57 j 33 i 10 \mathrm{i} 16013.10926 \mathrm{j} 0 \mathrm{j} 7 \&$ sourceid $=\mathrm{chr}$ ome\&ie=UTF-8 (www.hsdl.org), accessed on 29 Sep 2020.

Times of India Report, 14 Dec 2020. CPEC: Pakistan army to gain 'control' of \$60 billion Belt \& Road Initiative Retrieved from:

https://timesofindia.indiatimes.com/world/pakistan/pakistan-army-to-gain-control-of-60billion-belt-road-projects/articleshow/79720962.cms accessed on 15 Dec 2020.

Shivane, AB (09 Oct 2020). Chinese Coercion and Strategic Overstretch-The great fall of China, retrieved from https://www.linkedin.com/posts/lt-gen-a-b-shivane-pvsm-avsm-vsmretd-137a60128_chinese-coercion-and-strategic-overstretch-activity-6720260639501156352Jz8e accessed on 09 Oct 2020.

Singh, Abhijit (01 March 2016). India and the South China Sea Dispute-Recent developments have operations implications for India, The Diplomat. Retrieved form: https://thediplomat.com/2016/03/india-and-the-south-china-sea-dispute/ Accessed on 10 Oct 2020.

Singh, Abhijit (01 March 2016a). India and the South China Sea Dispute-Recent developments have operations implications for India, The Diplomat. Retrieved form: https://thediplomat.com/2016/03/india-and-the-south-china-sea-dispute/ Accessed on 10 Oct 2020.

Bose, Tapan Kumar (07 Aug 2020). India, China and the Neighbourhood in South Asia, The India Forum. Retrieved from: https://www.theindiaforum.in/letters/india-china-andneighbourhood-south-asia Accessed on 12 Oct 2020 